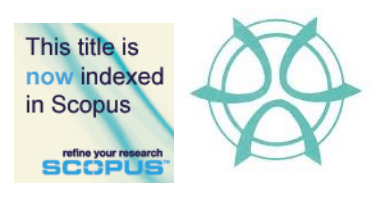

PLANNING MALAYSIA:

Journal of the Malaysian Institute of Planners

VOLUME 16 ISSUE 4 (2018), Page 34 - 39

\section{THE IMPACT OF LYNAS ADVANCED MATERIAL PLANT (LAMP) TOWARDS SURROUNDING HOUSING MARKET PRICE}

\author{
Muhammad Ikmal Ariff Azmee ${ }^{1}$ \& Atasya Osmadi \\ ${ }^{1} \& 2$ School of Housing, Building and Planning \\ UNIVERSITI SAINS MALAYSIA
}

\begin{abstract}
Lynas Advanced Materials Plant (LAMP) is situated in Gebeng industrial estate in Kuantan, Malaysia. Lynas plant processes rare earth elements that was trucked from Mt Weld Western Australia's mine site to Fremantle Port and then brought to Malaysia. Rare elements are important in greenhouse emission reduction especially for their distinctive use in wind turbines, hybrid vehicles, automotive chemical action converters and others technologies. However, the construction and the opening of Lynas plant may have caused pollution to the environment and health risk towards surrounding area. Few case studies highlighted the negative impacts of radioactive element towards the surrounding housing market price. Using before-and-after analysis and sensitivity analysis, this research seeks to evaluate the impact from Lynas plant on the price of housing (single storey terrace) in its surrounding area. The findings show that Lynas plant could be one of the factors that have affected the housing market price in the area. This research concludes that, in general, there is an increase of house price after the opening of Lynas plant, however it is evident that there is a trend of increasing house price when the house is farther away from the plant. It is hoped that the findings of this research helps in answering some of the public speculations regarding the impact of the plant.
\end{abstract}

Keywords: impact, Lynas, house, price 
PLANNING MALAYSIA

Journal of the Malaysia Institute of Planners (2018)

\section{INTRODUCTION}

Previous research have studied the impact of pollution or radioactive to the surrounding housing market price. Nelson (1981) observed the impact of residential property values, which resulted from the Three Mile Island (TMI) nuclear tragedy. According to him, although there are two government reports stated that the nuclear tragedy have caused losses in property values, more so residential properties closest to the plant, neither report utilised elementary statistical inference methods. Nelson's objective was to find out whether the nuclear tragedy caused a statistically decline in house price, which located inside a five miles radius from the plant. Nelson used an indulgent value model called hedonic model to look at the impact of TMI on sale costs of homes in two communities within the radius. Analysis on property values close to the TMI nuclear energy facility indicated that once the accident occurred, there was a brief term call on the quantity of sales of residences within ten miles from the plant. However, sales returned to normal within four to eight weeks. Hence, this proves that nuclear plant does bring impact to surrounding property market.

In the 1980s, the Asian Rare Earth (ARE) company, owned by the Mitsubishi Chemical Company, did not safely remove its industrial waste containing radioactive thorium hydroxide. Employees and also the neighbouring community were exposed to ionising radiation, leading to birth defects and cancer, especially leukaemia cases, among the 11,000 individuals living in Bukit Merah and Papan, Perak. Seven of the eight cases of cancer were fatal. Public protests eventually forced Mitsubishi Chemical to shut its operations in 1992. The clean-up had cost the company about US\$100 million (McCoy, 2013). Although the ARE case was not focussed on the impact of the rare earth plant on property value, it does show that such plant poses negative impact on the surrounding community. In the case of ARE, the area turned hazardous and not suitable for people to be living in.

In Gebeng, Kuantan, a rare earth plant was constructed and operated by Lynas Malaysian Sdn Bhd. However, property values do not seem to be affected by the plant existence. Property development remains active and this shows the confidence of the investors and entrepreneurs within the property sector and economic climate in Pahang, significantly in Kuantan ("Lynas tidak jejas nilai hartanah", 2012). In keeping with the report of the Pahang Property Valuation Department, the value of low-cost terrace homes in Jalan 10 Gambang has increased from RM49,000 to RM68,000 per unit, as well as for three storey shop houses in Jalan Beserah from RM700,000 to RM800,000 per unit (Husin, 2012). Additionally, the Lynas plant was also said to have attracted investments in various industries as well as offers more job opportunities, maximise the uses of Kuantan Port, together with native residents who are benefitting the spill-over of current economic impacts (Bernama, 2016). This proves that the existence of the Lynas plant brings positive impact towards the value of surrounding property. 
Muhammad Ikmal Ariff Azmee \& Atasya Osmadi

The Impact of Lynas Advanced Material Plant (LAMP) Towards Surrounding Housing Market Price

Nevertheless, some quarters objected to the statements that Lynas plant does not negatively affect surrounding property values (Muda, 2012). They contested that the statements have not been based on real facts and quite confusing. Thus, this study intends to analyse the impact of Lynas plant on the surrounding property values.

\section{METHODOLOGY}

This study employed the before and after analysis and sensitivity analysis to measure the pattern of average of percentage changes of property prices in the study area before and after the construction of Lynas Advanced Material Plant (LAMP). Secondary house price data for year 2004 until 2015 for four residential areas in Kuantan were obtained from the National Property Information Centre (NAPIC), Kuantan. The residential areas involved were Perumahan Bandar Baru Gebeng, Taman Idaman Bayu, Balok Jaya II and Balok Jaya. These four residential areas are made up of single storey terrace houses and are located near the Lynas plant.

\section{RESULTS}

Table 1 shows the percentage change of price of houses in Perumahan Bandar Baru Gebeng from 2004 to 2014. It can be seen that the prices were increasing from RM79,888 in 2004 to RM145,000 in 2014. The average of percentage change in house prices almost doubled after LAMP came into operation (8.18\%) compared to before $(4.68 \%)$.

Table 1: Average percentage change of single storey terrace house price in Perumahan Bandar Baru Gebeng before and after LAMP operation

\begin{tabular}{|c|c|c|c|c|c|}
\hline No. & Lot No. & $\begin{array}{c}\text { Date of } \\
\text { Valuation }\end{array}$ & $\begin{array}{l}\text { Price } \\
(\mathbf{R M})\end{array}$ & $\begin{array}{c}\text { Percentage of } \\
\text { Change }(\%)\end{array}$ & $\begin{array}{c}\text { Average of } \\
\text { Change }(\%)\end{array}$ \\
\hline 1 & 9396 & $23 / 10 / 2004$ & 79,888 & & \multirow{6}{*}{$4.68 \%$ (before) } \\
\hline 2 & 9390 & $31 / 10 / 2005$ & 79,888 & 0.00 & \\
\hline 3 & 9539 & $31 / 01 / 2006$ & 85,000 & 6.40 & \\
\hline 4 & 9368 & $11 / 07 / 2007$ & 95,000 & 11.76 & \\
\hline 5 & 9534 & $05 / 04 / 2008$ & 95,000 & 0.00 & \\
\hline 6 & 11096 & $05 / 05 / 2009$ & 100,000 & 5.26 & \\
\hline 7 & 11192 & $14 / 06 / 2010$ & 110,000 & 10.00 & LAMP Opening \\
\hline 8 & 11250 & $06 / 06 / 2011$ & 115,000 & 4.55 & \multirow{4}{*}{$8.18 \%$ (after) } \\
\hline 9 & 11170 & $25 / 01 / 2012$ & 125,000 & 8.70 & \\
\hline 10 & 11180 & $18 / 11 / 2013$ & 145,000 & 16.00 & \\
\hline 11 & 11181 & $13 / 12 / 2014$ & 150,000 & 3.45 & \\
\hline
\end{tabular}

Source: NAPIC Kuantan, 2017 
Table 2 shows the data for the transacted price of single storey terrace house in Taman Idaman Bayu from year 2004 to 2014. The lowest price recorded was RM94,000 in 2004, while the highest price was RM150,000 in 2014. This resulted in average percentage change of more than double after LAMP came into operation $(6.94 \%)$ compared to before $(3.22 \%)$.

Table 2: Average percentage change of single storey terrace house price in Taman Idaman Bayu before and after LAMP operation

\begin{tabular}{|c|c|c|c|c|c|}
\hline No. & Lot No. & $\begin{array}{c}\text { Date of } \\
\text { Valuation }\end{array}$ & $\begin{array}{l}\text { Price } \\
\text { (RM) }\end{array}$ & $\begin{array}{l}\text { Percentage of } \\
\text { Change }(\%)\end{array}$ & $\begin{array}{l}\text { Average of } \\
\text { Change (\%) }\end{array}$ \\
\hline 1 & 8785 & $07 / 07 / 2004$ & 94,000 & & \multirow{6}{*}{$3.22 \%$ (before) } \\
\hline 2 & 8786 & $08 / 04 / 2005$ & 94,000 & 0.00 & \\
\hline 3 & 8818 & $23 / 07 / 2006$ & 99,900 & 6.28 & \\
\hline 4 & 8731 & $20 / 03 / 2007$ & 100,000 & 0.10 & \\
\hline 5 & 8778 & $09 / 04 / 2008$ & 105,000 & 5.00 & \\
\hline 6 & 8781 & $04 / 07 / 2009$ & 110,000 & 4.76 & \\
\hline 7 & 10295 & $28 / 12 / 2010$ & 115,000 & 4.55 & LAMP Opening \\
\hline 8 & 10295 & $28 / 12 / 2011$ & 120,000 & 4.35 & \multirow{4}{*}{$6.94 \%$ (after) } \\
\hline 9 & 10285 & $13 / 04 / 2012$ & 125,000 & 4.17 & \\
\hline 10 & 8795 & $09 / 12 / 2013$ & 142,000 & 13.60 & \\
\hline 11 & 10305 & $30 / 10 / 2014$ & 150,000 & 5.63 & \\
\hline
\end{tabular}

Table 3 shows the data for the transacted price of single storey terrace house in Balok Jaya II from year 2005 to 2015. The lowest price recorded was RM100,000 in 2005, while the highest price was RM200,000 in 2015. The average of percentage change in house prices almost doubled after LAMP came into operation (9.40\%) compared to before (4.73\%).

Table 3: Average percentage change of single storey terrace house price in Balok Jaya II before and after LAMP operation.

\begin{tabular}{|c|c|c|c|c|c|}
\hline No. & Lot No. & $\begin{array}{c}\text { Date of } \\
\text { Valuation }\end{array}$ & $\begin{array}{l}\text { Price } \\
\text { (RM) }\end{array}$ & $\begin{array}{c}\text { Percentage of } \\
\text { Change }(\%)\end{array}$ & $\begin{array}{c}\text { Average of } \\
\text { Change (\%) }\end{array}$ \\
\hline 1 & 5841 & $05 / 08 / 2005$ & 100,000 & & \multirow{5}{*}{$4.73 \%$ (before) } \\
\hline 2 & 6138 & $03 / 01 / 2006$ & 110,000 & 10.00 & \\
\hline 3 & 6955 & $10 / 12 / 2007$ & 110,000 & 0.00 & \\
\hline 4 & 6646 & 09/07/2008 & 117,000 & 6.36 & \\
\hline 5 & 6956 & $20 / 11 / 2009$ & 120,000 & 2.56 & \\
\hline 6 & 7041 & $26 / 07 / 2010$ & 128,000 & 6.67 & LAMP Opening \\
\hline 7 & 5780 & $28 / 03 / 2011$ & 135,000 & 5.47 & \multirow{5}{*}{$9.40 \%$ (after) } \\
\hline 8 & 6718 & $20 / 04 / 2012$ & 145,000 & 7.41 & \\
\hline 9 & 7028 & $09 / 04 / 2013$ & 168,000 & 15.86 & \\
\hline 10 & 6121 & $08 / 05 / 2014$ & 180,000 & 7.14 & \\
\hline 11 & 6950 & $10 / 09 / 2015$ & 200,000 & 11.11 & \\
\hline
\end{tabular}


Muhammad Ikmal Ariff Azmee \& Atasya Osmadi

The Impact of Lynas Advanced Material Plant (LAMP) Towards Surrounding Housing Market Price

Table 4 shows the data for the transacted price of single storey terrace house in Balok Jaya from year 2005 to 2014. The lowest price recorded was RM95,000 in 2005, while the highest price was RM200,000 in 2014. This resulted in average percentage change of $12.98 \%$ after LAMP came into operation compared to $8.42 \%$ before LAMP.

Table 4: Average percentage change of single storey terrace house price in Balok Jaya before and after LAMP operation

\begin{tabular}{|c|c|c|c|c|c|}
\hline No. & Lot No. & $\begin{array}{c}\text { Date of } \\
\text { Valuation }\end{array}$ & $\begin{array}{l}\text { Price } \\
(\text { RM) }\end{array}$ & $\begin{array}{l}\text { Percentage of } \\
\text { Change }(\%)\end{array}$ & $\begin{array}{c}\text { Average of } \\
\text { Change (\%) }\end{array}$ \\
\hline 1 & 4065 & $05 / 11 / 2005$ & 95,000 & & \multirow{5}{*}{$8.42 \%$ (before) } \\
\hline 2 & 4058 & $16 / 03 / 2006$ & 98,000 & 3.16 & \\
\hline 3 & 4064 & $13 / 12 / 2007$ & 96,000 & -2.04 & \\
\hline 4 & 4074 & $12 / 08 / 2008$ & 115,000 & 19.79 & \\
\hline 5 & 4096 & $26 / 04 / 2009$ & 125,000 & 8.70 & \\
\hline 6 & 4035 & $13 / 05 / 2010$ & 125,000 & 0.00 & LAMP Opening \\
\hline 7 & 4056 & $19 / 12 / 2011$ & 125,000 & 0.00 & \multirow{4}{*}{$12.98 \%$ (after) } \\
\hline 8 & 4092 & $19 / 11 / 2012$ & 160,000 & 28.00 & \\
\hline 9 & 4054 & $07 / 01 / 2013$ & 170,000 & 6.25 & \\
\hline 10 & 4040 & $05 / 09 / 2014$ & 200,000 & 17.65 & \\
\hline
\end{tabular}

Source: NAPIC Kuantan, 2017

Meanwhile, Table 5 compares the average percentage change of house prices in the four residential areas based on their distance from LAMP. In terms of distance, among the four selected residential areas, the nearest to LAMP is Perumahan Baru Gebeng, which is located only $8 \mathrm{~km}$ from the plant. The farthest is Balok Jay, which is $14 \mathrm{~km}$ away from the plant.

Table 5: The Average percentage Change of House Price Based on Distance from

$$
\text { LAMP }
$$

\begin{tabular}{ccccc}
\hline Period & \multicolumn{3}{c}{ Average Percentage Change } & \\
\hline & $\mathbf{8 k m}$ & $\mathbf{1 2 k m}$ & $\mathbf{1 3 k m}$ & $\mathbf{1 4 k m}$ \\
\hline $\begin{array}{c}\text { Perumahan } \\
\text { Baru Gebeng }\end{array}$ & $\begin{array}{c}\text { Taman Idaman } \\
\text { Bayu }\end{array}$ & Balok Jaya II & Balok Jaya \\
\hline $\begin{array}{c}\text { Before } \\
\text { LAMP }\end{array}$ & $4.68 \%$ & $3.22 \%$ & $4.73 \%$ & $8.42 \%$ \\
\hline $\begin{array}{c}\text { After } \\
\text { LAMP }\end{array}$ & $8.18 \%$ & $6.94 \%$ & $9.40 \%$ & $12.98 \%$ \\
\hline $\begin{array}{c}\text { Percentage } \\
\text { increase }\end{array}$ & $3.5 \%$ & $3.72 \%$ & $4.67 \%$ & $4.56 \%$ \\
\hline
\end{tabular}


From Table 5, it can be seen that the residential areas farther from LAMP experienced higher percentage increase in their housing prices compared to those located closer to LAMP.

\section{CONCLUSION}

The findings from this research indicate that the construction and operation of LAMP do not negatively affect the house prices in its surrounding area. Despite mixed speculations on the impacts of LAMP, the housing prices in its surrounding have been increasing steadily even after LAMP came into operation. This could partly be due to the economic benefits the plant brought to the area. Previous research on impacts of nuclear facilities on property values by Bezdek and Wendling (2006) found that establishment of nuclear facilities has led to increase in property values and that the facilities also provided job opportunities to surrounding communities.

However, there is a strong pattern shown in Table 5 where, although all four residential areas continue to experience house price increase after LAMP came into operation, the biggest increase happened in residential areas farther from the plant.

\section{REFERENCES}

Bernama (2016, July 28). Lynas operation safe, generates only low-level radiation, says minister. Retrieved from https://www.malaysiakini.com/news/350292

Bezdek, R. H., \& Wendling, R. M. (2006). The impacts of nuclear facilities on property values and other factors in surrounding communities. International Journal of Nuclear Governance, Economy and Ecology, 1(1), 122-145.

Husin, N. N. (2012, March 27). Lynas project has not affected Kuantan market. Retrieved from https://www.thestar.com.my/news/nation/2012/03/27/lynas-project-hasnot-affected-kuantan-market/\#ZImpzkegS6fLrvPg.99.

Lynas tidak jejas nilai hartanah. (2012). Retrieved from http://ww1.kosmo.com.my/kosmo/content.asp?y=2012\&dt=0327\&pub=Kosm o\&sec $=$ Negara\&pg=ne_07.htm

McCoy, R. (2013, March 9). Launch of report on the description and critical environmental evaluation of the Lynas Advanced Materials Plant in Gebeng, Pahang. Retrieved from http://mpsr.org/wp/2013/03/09/report-on-lynasenvironmental-hazard/

Muda, M. N. (2012). PKR tuntut MB beri fakta nilai hartanah melonjak kerana Lynas. Retrieved from http://www.freemalaysiatoday.com

National Property Information Center, Kuantan (2017). Property Reports.

Nelson, J. P. (1981). Three Mile Island and residential property values: Empirical analysis and policy implications. Land Economics, 57(3), 363-372 